\title{
THE CULTURAL - HISTORICAL RESOURCES FROM DOBROGEA, ROMANIA- POTENTIAL LOCAL SOURCE OF ECONOMIC GROWTH AND EDUCATION
}

DOI: https://doi.org/10.18509/GBP210405d

UDC: 338.483.12:338.121(498)

338.483.12:37(498)

\author{
Alina Viorica Dumitrascu ${ }^{1}$ \\ Camelia Teodorescu ${ }^{2}$ \\ Laurentiu-Stefan Szemkovics ${ }^{3}$ \\ Andrei Ducman ${ }^{2}$ \\ Bogdan Petre ${ }^{1}$ \\ ${ }^{1}$ University of Bucharest, Faculty of Geography, "Simion Mehedinti" Doctoral Scool, \\ Bucharest, Romania \\ ${ }^{2}$ University of Bucharest, Faculty of Geography, Department of Human and Economic \\ Geography; Bucharest, Romania CAIMT (Research Center for Integrated Analysis and \\ Territorial Management), University of Bucharest, Romania \\ ${ }^{3}$ National Central Historical Archives, Bucharest, Romania
}

\begin{abstract}
The evaluation of the archeological and cultural potential represent essential elements of designing a complex study that may generate effects upon the durable tourism in a certain geographical area. The research aims to identify the monuments that are capable to satisfy the requirements imposed by the cultural and tourism- purposed activities by: accessibility, originality, old age, conservation state or maintenance or level of rehabilitation and promotion. The geographical areal under analysis is the historical and geographical province of Dobrogea, in Romania. It is a historical province of great value, while the present monuments have a particular feature connected to their old age, as well as certain particularities connected to their multi-ethnicity co-existing in this geographical areal. The methodology follows firstly the Cultural Monument List made up by the Ministry of Culture of Romania. On the second stage, there follows the analysis, on the field, of each monument enlisted and the establishment of the degree of cultural and tourism-purposed valorization, in compliance with the criteria already specified. The results of the study shows first of all a difference between the number of cultural monuments present, the value of which is undoubtedly extremely high, and the degree of valorization they benefit of. The exigencies of the tourists do not allow their being introduced and used into the tourism-purposed circuit or in the tourism offers regarding the monuments that have a very low degree of accessibility, originality and rehabilitation level.
\end{abstract}

Keywords: culture, archeological potential, education, multi-ethnicity, tourist circuits

\section{INTRODUCTION}

The cultural-historical monuments have represented and continue to represent, one of the most important resources regarding the cultural information of a region, and, to the same extent, they represent a form of cultural and historical education [14], [23], [22], [17]. Dobrogea abounds in such resources, being a region with an extremely rich historical 
past. From the Greeks to the Romans, Ottomans or Slavs, a lot of populations have travelled through this place, leaving behind important material traces [10], [13], [1], [11], [15]. Out of these, the current study analyzes two of the most important monuments of the land comprised between the Danube and the Black Sea (fig. 1). The visibility of these cultural-historical monuments must become greater and greater, this being a necessity in order to know the places with historical significance. [19], [3], [2], [16].

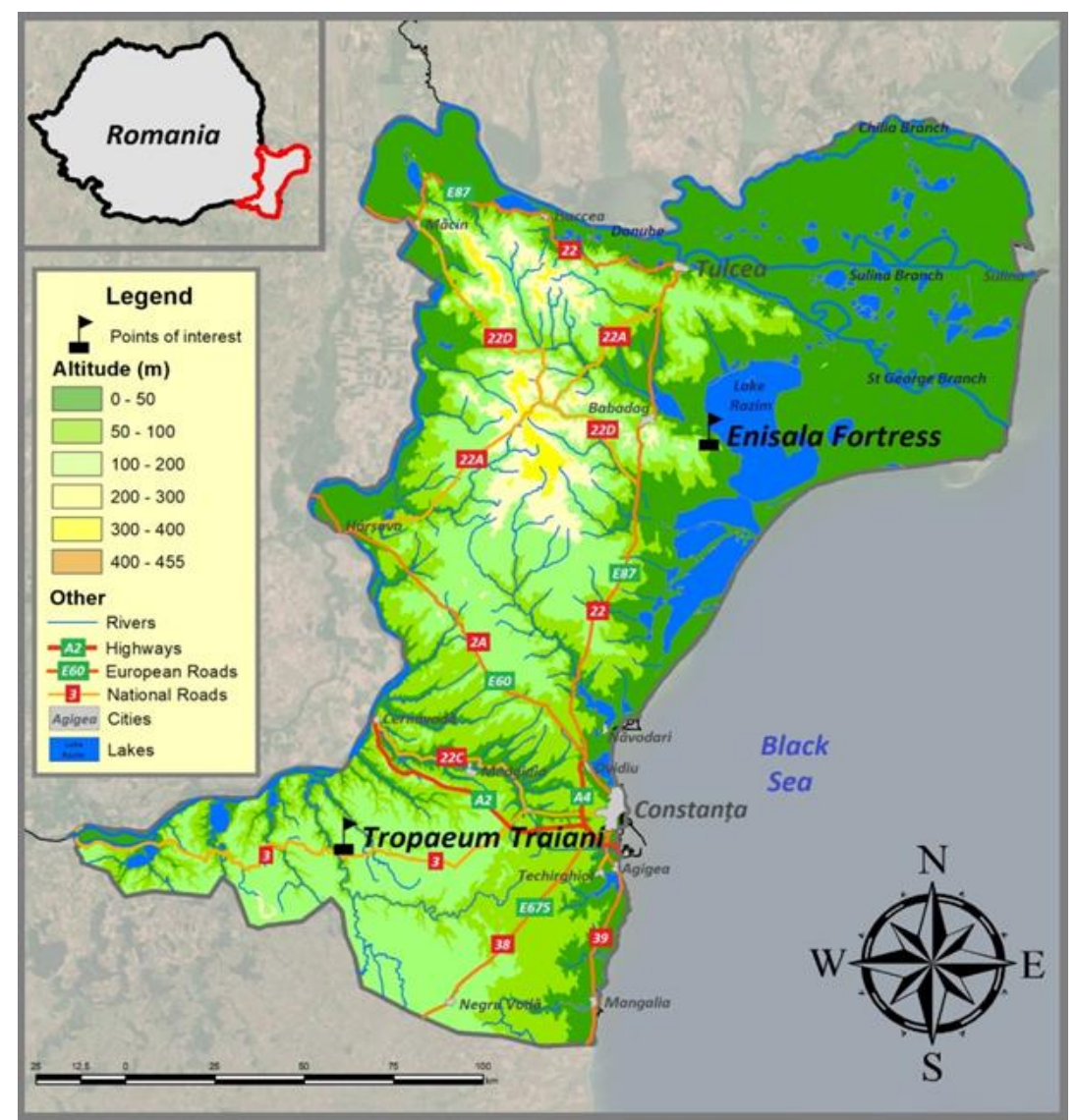

Figure 1. Location of Tropaeum Traiani and Enisala fortresses in Dobrogea province, Romania

The first written pieces of information about the existence of the Adamclisi artefacts date back only to the 19th century, when several researchers tried to assess the authenticity and the state of decay of the archaeological ensemble from Adamclisi. From the very beginnings, both the citadel and the monument were set up by Emperor Traian as a symbol of Roman power following the defeat of the Geto-Dacians and their allies in the battle from the Adamclisi fields in 102 [12]. Studies reveal the fact that the entire commemorative complex in which the triumphant Tropaeum Traiani monument is included, was built from 102 until 109 A.D. and the designer seems to have been the very Apolodor from Damascus. [12]. Once water pumps started being built in Dobrogea, after 1856, stone blocks from the Adamclisi ensemble were used, especially in the upper part. After the War of Independence, in 1882, archaeological excavations started and they were led by Grigore Tocilescu [21]. He also wrote a monography of the Tropaeum Traiani monument, in which, among others, he mentioned the fact that the monument was dedicated by the Romans to the God Mars. The Tropaeum Traiani Monument was rehabilitated in 1977; this was a difficult procedure caused by the lack of a greater part of the construction which had been destroyed ever since the Antiquity [12]. Equally, the 
study follows into the footsteps of the construction and the special situations that the Enisala Citadel, another Dobrujan symbol, went through. The Enisala Fortification was part of the chain of Genoese colonies, which encompassed the cities from the Danube Delta - Chilia and Likostomion, the White Citadel from the mouths of the Dniester, Caffac in south Crimea. Between 1397-1416 the Enisala Citadel was part of the defensive system of Wallachia during the reign of Mircea the Elder. After Dobrogea was conquered by the Turks in 1419-1420, an Ottoman military garrison was established in the citadel. Most of the precinct walls are kept at a height of 5-10 m and can be easily noticed from long distances [9].

\section{METHODOLOGY}

The methodology follows, first of all, a few basic steps; the starting point is represented by the selection of the two cultural-historical monuments - The Tropaeum Traiani Citadel and the Enisala Citadel from the Cultural Monument List made up by the Ministry of Culture of Romania. The next stage focuses on: field analysis for each monument, making a decision regarding the degree of cultural and touristic valorisation, according to its accessibility, originality and restoration, possibly the preservation of the existent material traces. According to these elements, each of the two monuments can represent a real source of information used especially in the educational process. An analysis alongside the young generation must be made by means of specific didactic means, as it offers a huge advantage based on discovery.

\section{RESULTS}

The historical importance of the two cultural-historical monuments is well-known. From a touristic and educational perspective, the present study intends to emphasize their importance, according to the results obtained. Once brought to surface, the walls of the citadel started to gather a great importance for the culture and history of these places, at the same time becoming a real source of tourism and education.

What we can see today are only parts of this important monument, such as the sewer system and the civilian constructions (fig. 3 and fig 4). The outer walls are the original ones, and they also include some stair niches, which means that the citadel used to be a multi-storey one. The eastern and western gates, which most probably were not strictly for pedestrians, are connected to a main street provided with a large aqueduct. Traces of the constructions which had a religious purpose and significance are quite well preserved, offering a good visibility from a touristic point of view and also when it comes to explaining History lessons.

Documents certify to the fact that the citadel was abandoned starting with the 7th century, after invasions from the Huns and the Avar-Slavs. Nevertheless, the constructions belonging to the Dridu culture, dating back to the 9th - 10th centuries [12] are noticeable. The Tropaeum Traiani Citadel was built after the Dacian-Roman wars, and an inscription on the statue of Trajan discovered during the excavations, shows the fact that it was completed in 116 A.D. In the 4th century it was enlarged, encompassing a surface of approximately $10 \mathrm{ha}$, and an annex was added in the south-east area, outside the outer wall [12]. It was provided with four entrances, of which only two have large sizes, the ones in the east and in the west (fig. 2 and fig. 5). 


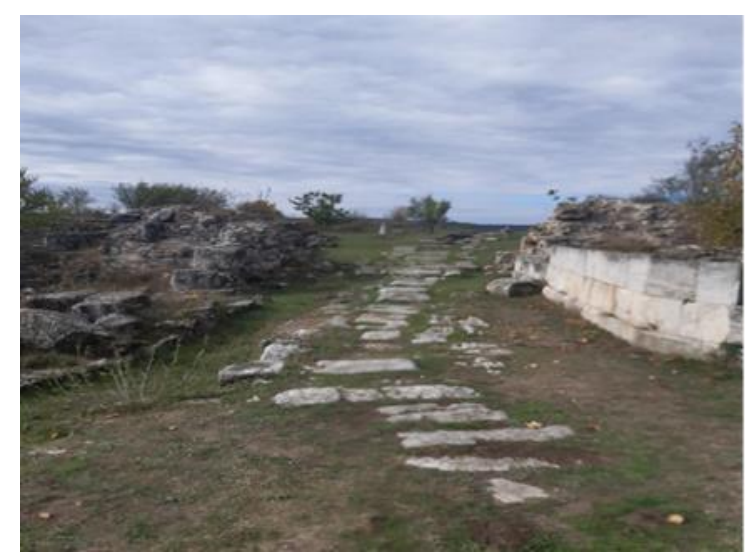

Figure 2. The Tropaeum Traiani citadel-view from the Eastern gate

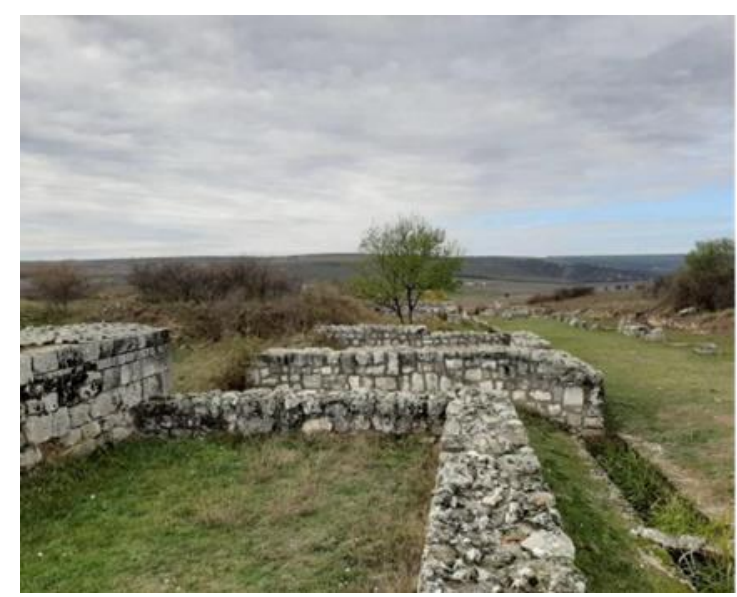

Figure 4. The Tropaeum Traiani citadel -Civilian constructions

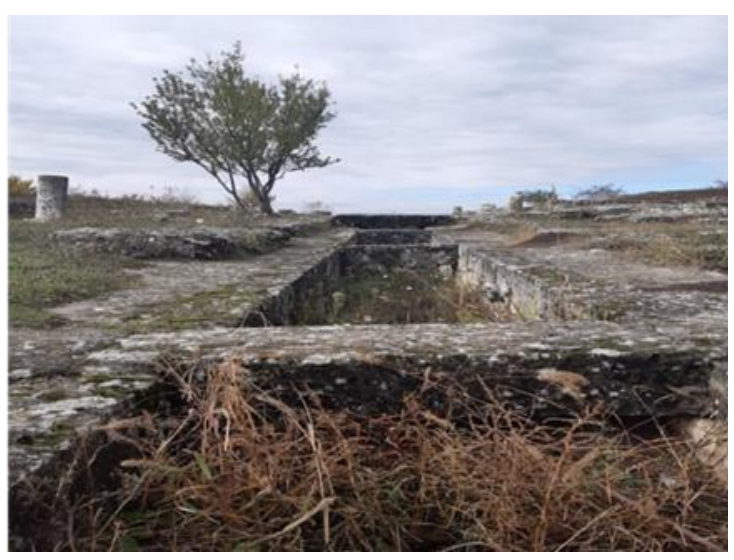

Figure 3. The Tropaeum Traiani citadel-the sewer system alongside the main road

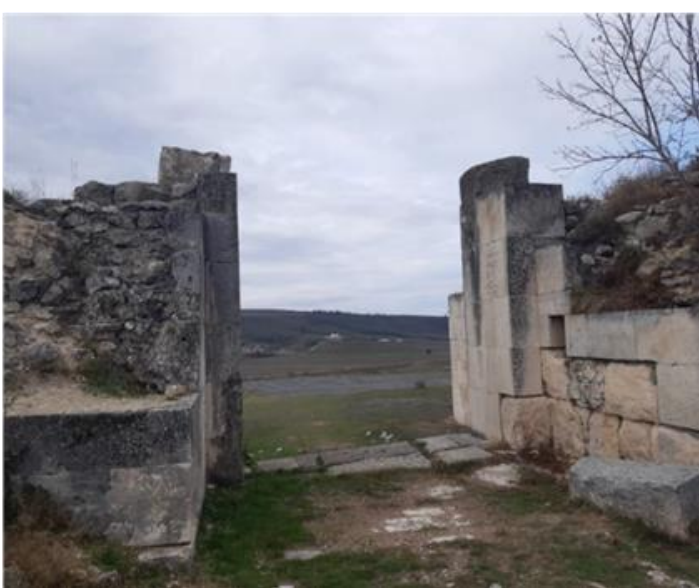

Figure 5. The Tropaeum Traiani citadel-The western Gate

Other important material traces are shown by Basilica Forensis which was very well preserved, just like all the details having to do with the architectural peculiarities of a place of worship (fig. 6 and fig. 7).

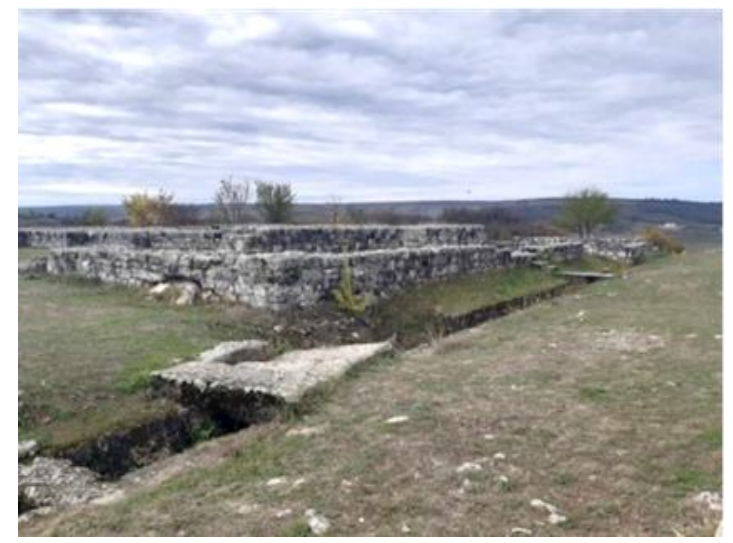

Figure 6. The Tropaeum Traiani citadel -Basilica Forensis

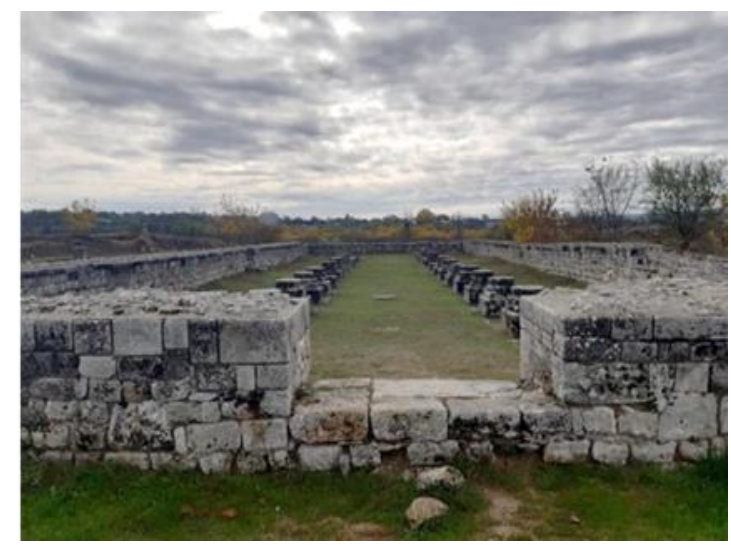

Figure 7. The Tropaeum Traiani citadel-Entrance to Basilica Forensis 


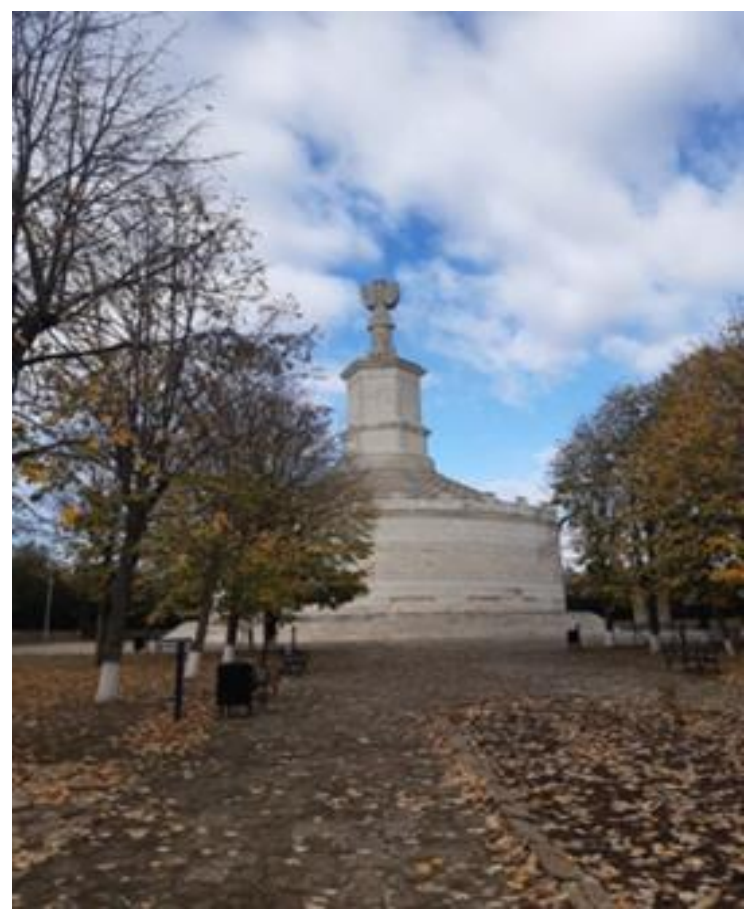

Figure 8. The Tropaeum Traiani Monument

As for the touristic circuits, the historical site is visited by a reduced number of tourists (on average below 550 tourists /month - in 2019, given the fact that in 2020 the statistics is influenced by the COVID 19 pandemic), despite being extremely well-known in Romania due to its presence in the History course-books.

At the same time, visiting the place presupposes certain costs, if we take into account the fact that there are many other touristic objectives in the area, whereas accommodation and catering are missing [7], [8], [18], [5], [20].

At the end of 2019 the first and only accommodation was registered in Adamclisi - The Trophaeum Traiani Pension. The accommodation capacity in 2019 included 30 vacancies. This is not enough to develop mass toursism, despite the fact that amenities to support a larger number of arrivals have taken place, both in the archaeological site and in the museum (fig. 8). As for the touristic arrivals, if we analyze the data starting with the first month of 2019, we can notice a certain seasonality. Thus, the largest number of tourist arrivals are registered in the warm months, July, August and September. Firstly, during the colder months when the wind is more powerful, it is much more difficult to visit the historical site, as it is located in a relatively open space. Thus, the temperatures are felt to be lower and disconfort is greater for tourists. On the other hand, during winter, travelling to this historical site is difficult, access being possibile on only one road with asphaltic pavement which is deteriorated. Considering their historical significance, their cultural role and their huge educational potential, The Tropaeum Traiani Citadel, the Adamclisi Monument, and the Adamclisi Museum belong to the category of those cultural monuments which, despite having a reduced degree of visitation, display high values for originality and preservation. Unfortunately, a lower score is registered for accessibility. The second monument analyzed is the Enisala Citadel. The West-South-West precinct was built on the steep edge of the promontory (fig.9).

The citadel is shaped as a trapeze or irregular quadrilateral, with the West-South-West side almost completely destroyed, with a length of more than $100 \mathrm{~m}$; the Eastern and the Northern sides are of approximately $50 \mathrm{~m}$, and the Southern one has almost $30 \mathrm{~m}$. The 
precinct wall is $1,50-1,85 \mathrm{~m}$ thick and on the outside it shows eight defense towers with three, four and five sides (fig. 10).

Both the enclosure wall and the towers are built from carved, wrought, cubic limestone of small and middle sizes. The entrance (on the Southern side) used to be done through a gate with a very high opening, provided with a double arch and defended by a massive pentagonal bastion. The second enclosure wall of the fortification located on the NorthEast side is provided with square and triangular towers (fig. 11).

After 1991 the citadel walls, which had been ruined by bad weather, were restored, accessibility being very good. At the same time, originality, the existence of panels and informational materials, the belvedere amenities, managed to turn the Enisala Citadel from a barely-visited monument into one which has become important from a touristic point of view. Another advantage is its geographical location, as it is situated next to the traffic artery between Constanta and Tulcea, near Babadag and the lake with the same name. The development of such a monument is a gain both for the local population and for the tourism consumers [4], [6], [20].

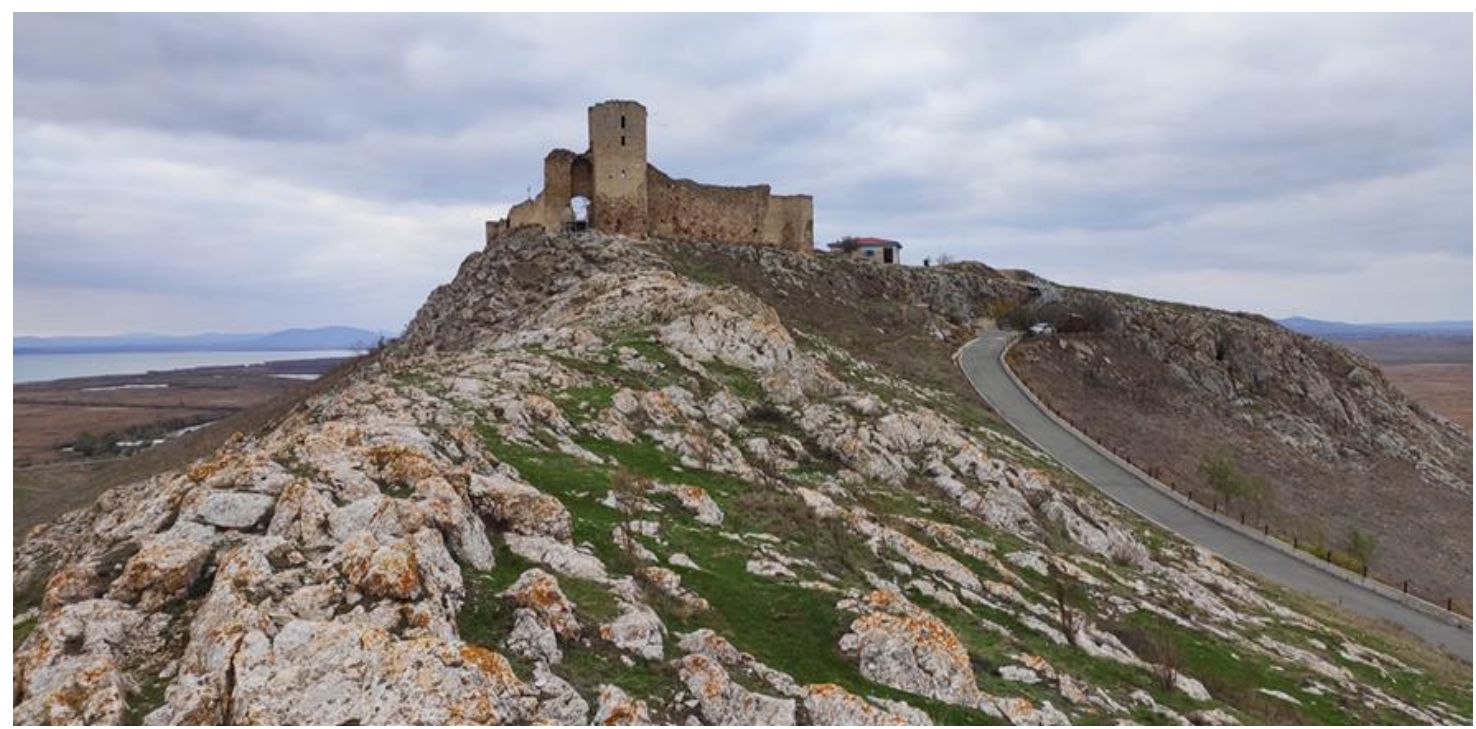

Figure 9. The Enisala Citadel - outer view from the South

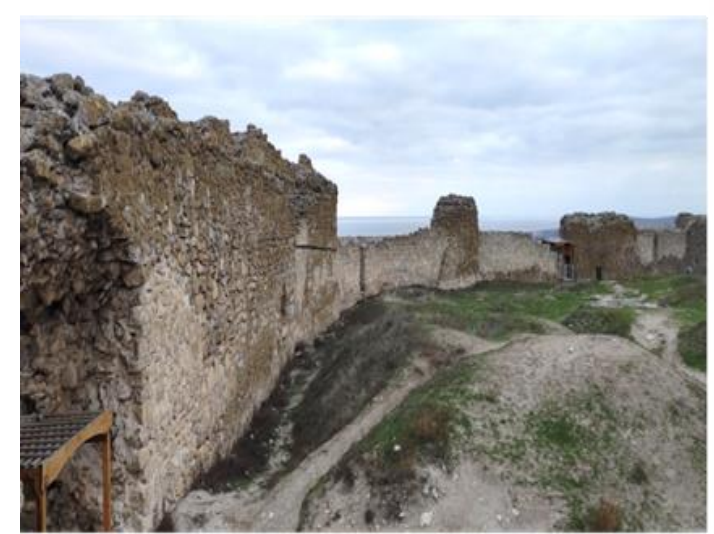

Figure 10. The Enisala Citadel - inner view of the wall

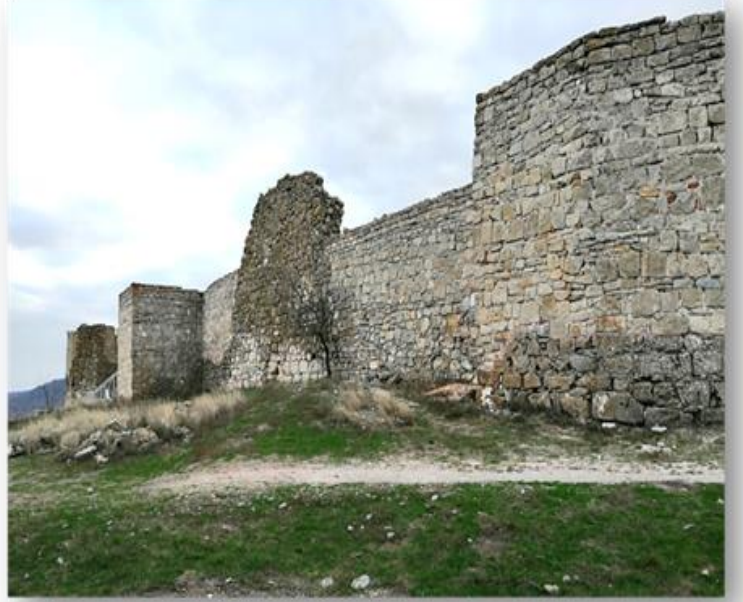

Figure 11. The Enisala Citadel - outer view of the North-East wall 
There should be a permanent relationship between the historical monuments, the cultural monuments, the touristic and educational activities. This type of relationship favors the cultural-historical knowledge, which, in turn, ensures in the long run, respect for the history and culture of each Romanian geographical area. These two monuments, one dating from the antique period and the other from the medieval period, represent only a part from what Dobrogea has to offer in terms of cultural-historical information. Many of the monuments from this Romanian area, Dobrogea, are included in the Monument List, drawn up by the Ministry of Culture from Romania, but they are either not visible in the field or they are in a state in which they cannot be valorized from a touristic perspective. We must be aware of the fact that these inconveniences will not be improved within a short period of time. This is precisely what should guide us towards valorizing the monuments which have already gone through a process of restoration, preservation. Once rebuilt, these monuments would facilitate access from the main arteries, offer certain benefits to those who are setting up a business in the field of tourism, irrespective of whether it is in terms of accommodation or food industry, or one concerned with touristic information, so they would support the entire touristic process, with beneficial effects both for the residents and for the tourism consumers. The residential population would benefit from earning additional income offered by the newly-created jobs as well as from valorizing their own products (agriculture, handicraft etc.).

\section{REFERENCES}

[1] Barrera-Fernandez D. \& Hernandez-Escampa M., The impact of urban policy in the management of the tourist-historic city: a comparative study, Pasos-Revista de Turismo y Patrimonio Cultural, vol. 14, Issue 3, pp 705-724, 2016

[2] Besculides, A., Lee, M.E. \& McCormick, P.J., Residents' Perception of the Cultural Benefits of Tourism, Annals of Tourism Research, Vol. 29, No. 2, pp 303-319, 2002

[3] Costa Hilário, Ana Catarina \& Marreiro das Chagas, Márcio, Influencia del escultismo en la formación personal y social de los scouts por medio de la práctica del turismo ecológico y pedagógico, Estudios y Perspectivas en Turismo, vol. 23, Issue 3, pp 484-50, 2014

[4] Dincă Iulian \& Camelia Teodorescu, The Romanian rural space and its landscapes: attraction and motivation for relocating townspeople, Geographia Napocensis, vol. 1, pp 21-36, 2015

[5] Gursoy, D., Jurowski, C. \& Uysal, M., Resident Attitudes: A Structural Modeling Approach, An $\neg$ nals of Tourism Research, vol. 29, No. 1, pp 79-105, 2002

[6] Herman G.V. \& Varnav R., Design elements for promoting attraction case study: Tara Oasului museum (Satu Mare County), Geojournal of tourism and geosites, vol. 14, Issue 2, Oradea, Romania, pp 168-177, 2014

[7] Hocaoglu D.A., The Role of Design in Cultural Heritage Based City Branding of Beypazari, Milli Folklor, vol. 109, pp 217-232, 2016

[8] Ilieș D.C., Baias Ș., Buhaș R., Ilies A., Herman G.V., Gaceu O., Dumbrava R. \& Măduța F.M., Environmental education in protected areas. Case study from Bihor county, Romania, Geojournal of tourism and geosites, vol. 19, Issue 1, pp 126-132, 2017

[9] Iosipescu Raluca \& Iosipescu Sergiu, Cetatea Ienisala, Contribuții istorice și arheologice la proiectul de restaurare, Revista Monumentelor Istorice, București, Romania, vol. 1, pp. 109-124, 2009

[10] Mureșan, I.C., Oroian, C.E., Harun, R., Arion, F., Porutiu, A., Chiciudean, G., Todea, A. \& Lile, R., Local Residents' Attitude Toward Sustain $\neg$ able Rural Tourism development, Sustainability, Vol. 8, pp 2-14, 2016 
[11] Noel Biseko Lwoga, Heritage proximity, attitudes to tourism impacts and residents' support for heritage tourism in Kaole Site, Tanzania, Bulletin of Geography. Socio-economic Series, No. 42, pp 163-181, 2018

[12] Papuc Gh. \& Bodolica Vitalie, Despre amplasarea metopelor de la monumentul triumfal Tropaeum Traiani, Revista Pontica, Muzeul de Istorie Natională si Arheologie, Constanta, Romania, vol. 41, pp. 393-402, 2008

[13] Pintilii Radu-Daniel, Daniel Peptenatu, Ana-Maria Ciobotaru, Sorin George Toma, Ana Maria Grigore, Cristian-Constantin Drăghici, Răzvan-Cătălin Dobrea, Adrian Gabriel Simion, Ion Andronache, Camelia Teodorescu \& Daniel Constantin Diaconu, Creative economies in Romania-spatial projections and trends, Bulletin of Geography. Socio-economic Series, Poland, vol. 37, pp 95-108, 2017.

[14] Rădoi Irina-Valentina, Andrei Ducman, Camelia Teodorescu, Marian Marin, Alexandru Gogioiu, The impact of the development of the local economy on the natural environment of the Danube Delta, Romania, Proceedings, Public recreation and landscape protection, Krtiny, Czech Republic 2020, pp. 489

[15] Teodorescu Camelia \& Laurentiu Stefan Szemkovics, The ethno-creativity in the pilot centers in Romania and their role in the development of cultural tourism and the educational process, Forum geografic Geographical studies and environment protection research, Craiova, Romania, vol. 16, nr. 1, pp. 88-97, 2017

[16] Teodorescu Camelia, Daniel Diaconu \& Roxana Radu, Disfunctionalities in the Organization and Development of SPA Tourism Developed on Salt Resources in Maramures, Romania, Public Recreation and Landscape Protection, vol. 1, pp 101-105, 2019

[17] Teodorescu Camelia, Octavian Teodorescu, Nicoleta Bira, Badea Alin \& Badea Livia Florina, Religious and cultural tourism and the socio-economic and educational implications, Quaestus Multidisciplinary Research Journal, Romania, vol. 8, pp 227-285, 2016

[18] Teodorescu Camelia, Radu-Daniel Pintilii, Peptenatu Daniel, Teodorescu Octavian \& Toma Sorin George, Popularizing Cultural Identity Through Religious Tourism-Socio-Economic and Educational Implications, International Multidisciplinary Scientific GeoConference: SGEM: Surveying Geology \& mining Ecology Management, Bulgaria, vol.3, pp 947-954, 2016

[19] Teodorescu Camelia, Turism cultural, Editura Transversal, Targoviste, Romania, 2009

[20] Camelia Teodorescu, Radu Vânturache, Octavian Teodorescu \& Daniel Constantin Diaconu, Proposal For Functional Conversions-Faur Area, Bucharest, URBANISM. ARHITECTURA. CONSTRUCTII, vol. 7, Issue 2, pp 137-146, Bucharest, Romania, 2016

[21] Tocilescu Grigore, Castrul Tropaeum-Traianum de la AdamKlissi, Muzeul National de Antichitati, Bucuresti, Romania, 1892

[22] Torre, A. \& Rallet, A., Proximity and Localizaרtion, Regional Studies, vol. 39, No. 1, pp 4759,2005

[23] Twining-Ward, L. \& Butler, R., Implementing STD on a Small Island: Development and Use of Sus $\neg$ tainable Tourism Development Indicators in Samoa, Journal of Sustainable Tourism, vol. 10, pp 363- 387, 2002 